\title{
Reflections on the journey: six short stories
}

\author{
Sharon L Haynie ${ }^{1 *}$, Amber S Hinkle ${ }^{2}$, Nancy L Jones ${ }^{3}$, Cheryl A Martin ${ }^{4}$, Paula J Olsiewski ${ }^{5}$ and Mary F Roberts ${ }^{6}$
}

\begin{abstract}
One of the goals of the 2011 International Year of Chemistry is to celebrate the contributions of women to science. A question that has been frequently asked in this regard is... Why is it necessary to highlight women in the "age of equality"? The reasons are varied but the facts are that many women scientists worked in obscurity throughout the $19^{\text {th }}$ and even well into the $20^{\text {th }}$ century, sometimes publishing anonymously to be heard. This celebration of Women in Science is one way to recognize both the resiliency and passion of these women. As part of this celebration, Chemistry Central Journal's Thematic Series of "Women in Chemistry" includes this article describing the path several women took as they pursued chemistry careers spanning the latter part of the $20^{\text {th }}$ century and into the early $21^{\text {st }}$ century. Sharon Haynie, Nancy Jones, Cheryl Martin, Paula Olsiewski, Mary Roberts and Amber Hinkle each have unique story of their personal journey from childhood to adulthood. As you read these stories, listen generously, and feel free to share your own stories, comments and thoughts.
\end{abstract}

\section{Introduction}

In science, we tend to focus on ideas not people and events. We revel in and revere technical triumphs. The personal journey to claim the privilege to participate in the science enterprise can also offer a starting point for inspiration, so six women chemists were invited to reflect on their journeys. The starting point varies from early childhood, high school, graduate school to the first professional appointment. A common theme emerges: curiosity meets challenges. As the saying goes "... all stories are true".

\section{What it is to be a woman scientist}

\section{Nancy L. Jones (Figure 1)}

How have things changed for me since I began my journey?

I was curious about how things worked as I was growing up. Not the 'let-me-take-it-apart' kind of curious, more like 'What does it do?' How were those kittens born? Why is there math? I read volumes of our encyclopedias. Math classes were fun. I don't remember much about science classes which makes me think they weren't very memorable. I do remember academic competition, boy vs. girl. In 7th grade my math teacher told us it irritated him to have to give me the award for highest average rather than a boy. At the time I thought

\footnotetext{
* Correspondence: Sharon.L.Haynie@usa.DuPont.com

${ }^{1}$ Central Research Department, DuPont, Wilmington, Delaware, USA

Full list of author information is available at the end of the article
}

it was a joke. I moved to a girls' high school where the science curriculum was very weak and there were no role models in science. Math on the other hand was challenging and fun (Is that redundant?). My teachers encouraged me to work at my own (speed of light) pace and spent time with me one-on-one fleshing out the intricacies of geometry and trigonometry. Math in my senior year should have been Calculus but it wasn't offered at my school and no one felt we were 'prepared' for it so a few of us walked across the street to the boys' school every morning for a pre-calculus class. That was an eye-opener. It was palpable that those young men most certainly did not want to be shown up by any girls. But we couldn't help ourselves.

Then to college. I'm not sure whatever possessed me to declare a major in Chemistry. It wasn't because I had had such a mind-blowing experience in high school. Maybe it was the challenge. Maybe Chemistry felt to me like the core of everything. There weren't too many women in the major; I was one of only two women to graduate with a BS degree and no women on the faculty. I felt aimless though, liked what I was doing but not sure at all where I was headed. When it came time to find a senior research project, it was a professor who invited me to join his group rather than me asking him to join. That was the moment of all things good. He and his graduate students mentored me. We talked about research, careers, teaching, living the graduate student life. They encouraged me to pursue graduate school and I did. 


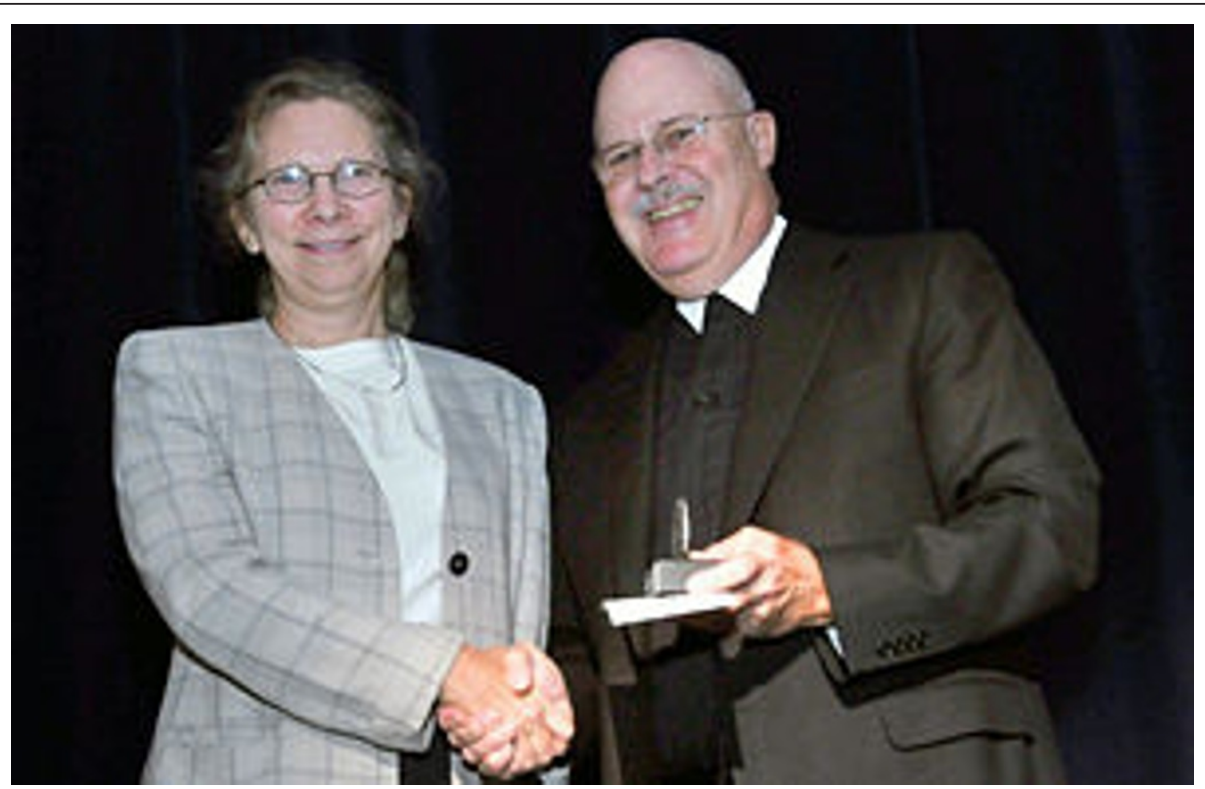

Figure 1 Photo of Nancy receiving the Distinguished Lasallian Educator Award in 2010

In graduate school, I still had not seen a single woman chemistry faculty. But there were so many woman grad students and post-docs I don't think I noticed. With many of the professors, research or teaching, I never noticed any gender differentiation at all. But with some, oh yes I did. While on a site visit and job interview, I was shocked when my host asked me about my fiancé. Funny though, because I didn't have one. A faculty member had 'shared' that with the campus recruiter. In my own research group, our advisor was sensitive, fair, and even, just about perfect. (I'm sure I didn't express it like that back then.) In my first postdoctoral position I overheard a faculty say, "Her husband has a job and he makes plenty of money." In my second, my husband, a chemist, was the one showered with attention by my professor. But it was there that for the first time I was treated as a role model, that my behavior, my words, my successes were held up as an example.

I never thought I would ever teach. I landed in a oneyear teaching position at a women's college. Talk about being a role model. The students were eager to learn 'how to do it.' What did they need to know in order to go out into the world and find their successes? It was very rewarding to see so many go on to Chemistry $\mathrm{Ph}$. D. programs, professional schools, and industry positions. And I was smitten by teaching. I wanted to do more.

Now I am a member of the faculty at La Salle University. I started as the only woman in the Chemistry Department and I think one reason I was offered the position was to serve as a role model for all the students, women are chemists too. My colleagues were and are still all fantastic. We all have the same mission, teaching our students to think critically, to solve problems, and to be good citizens in our global society. It is uplifting for me to work with a group who believes in what I believe in. We can support each other, challenge one another, and collaborate on ways to teach our students. For me, teaching happens in the classroom, in the lab, with research students, and especially outside the classroom, with new students and with those ready to graduate, and even with those who come back or stay in touch. I am amazed at how lasting these relationships are. In my first class there, Advanced Inorganic Chemistry, there was a young woman who wanted to pursue a Ph.D., agonized over which school to choose, was shocked when I wouldn't choose for her, and was very, very successful in her program and in her career. She has become a leader within her company. Another student, a young man who did not know that graduate school was even an option, was persuaded to apply for national fellowships, was awarded one, and was successful in obtaining his Ph.D. Teaching took up almost all of my time. After my first year, I participated in a NSF-Solid State Chemistry Summer Program right about the time high temperature superconductors were causing all kinds of excitement. I spent the summer with John Corbett at Iowa State University working on new structures for inorganic compounds. This new area, for me, energized my teaching and more students went off to pursue advance degrees in solid state chemistry. Research was for the summers, teaching occupied all my time during the semesters. I was fortunate to be able to work in the labs of Art Sleight and Joe Calabrese at DuPont for four summers. 
At this point, I became Chair of the department. Teaching and administration left me with less than no time for research and I had to face up to that. In addition to juggling teaching and administration, we had two children and time management and flexibility were imperative. And after three years as chair I became involved in developing a new program, Integrated Science, Business, and Technology (ISBT), for which I am now chair. Graduates of this program are ready to hit the ground running. The coursework, laboratory, group projects, independent research, internship and coop experiences, are all designed to help our students to become self-starters, leaders, collaborators, and good citizens. This was a very different experience for me. I had never had 'a real job' outside of academia. I now work with two faculties who have had significant and varied experience in industry and have taught me vast amounts about 'the real world.'

And the constant that runs along the path I have taken is the students. I know first-hand the value of a great mentor, that teacher who makes you sit up excited, the advisor who listens, just listens. I was honored in August to be named the Lasallian Distinguished Educator for 2010. I hope I have touched some student, even slightly, such that he or she was inspired to continue on in science and to become a scientist themselves.

\section{With a degree in chemistry, you can go anywhere! Cheryl A. Martin (Figure 2)}

My twenty-plus year career in the chemical industry has taken me (so far) from Cambridge, MA to Philadelphia, PA to Geneva, Switzerland, to Menlo Park, CA allowing me to travel to many places around the world, meet amazing people and learn so many things. My career path has been diverse: starting out as a synthesis chemist with Rohm and Haas, later moving to research management and then marketing, a big leap (without an MBA) into investor relations, corporate financial planning and finally general management (overseeing operations, sales, marketing and technology) in both the US and Europe. I am currently at Kleiner Perkins Caufield \& Byers, a venture capital firm based in Menlo Park, CA, researching investment opportunities, assisting portfolio companies with strategy and negotiation, and even stepping into one of them as interim CEO. I am in the midst of a career that I could not have predicted, but looking back, can see threads running back through to my education at both Holy Cross and MIT. We can all learn a lot about ourselves in school especially if you listen to that 'inner voice' that calls out your passions. For me, beyond the obvious of an outstanding education in chemistry, I truly value my early experiences around leadership, how technology is used and international perspective.

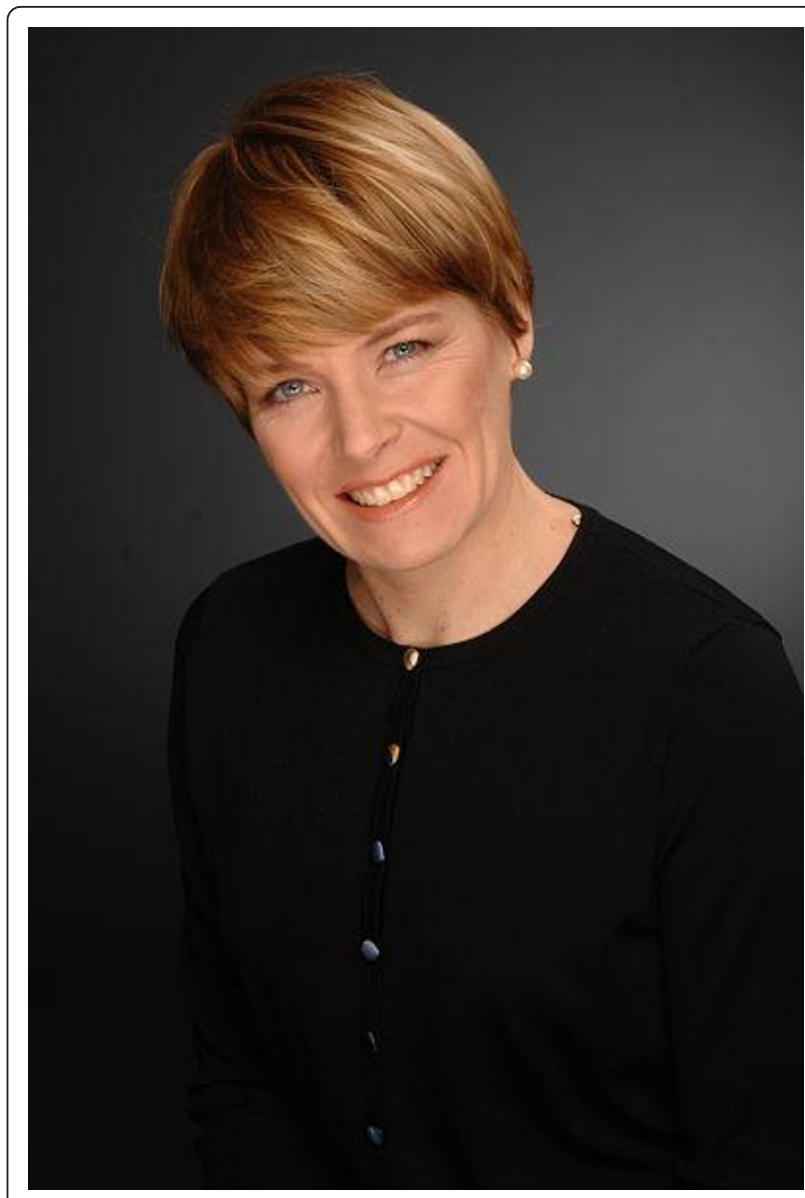

Figure 2 Photo of Cheryl A. Martin

My two earliest jobs in chemistry were as a teaching assistant-in both the lab and classroom. Through those experiences I started developing my teaching, leadership and influence skills and definitely had fun working as part of a team! A group of women in the chemistry department at MIT started a lunchtime discussion group to meet and share ideas - certainly nothing like today's Women in Chemistry organization, but a nascent version which was useful to all of us. Just getting together away from the day to day of the lab, sharing observations and discussing issues made it all so much more manageable-(and the cookies were always a big draw)!

A second area that absolutely shaped my future career was my fascination with 'How is the chemistry used? Who will benefit from it?" My PhD advisor was Prof K. Barry Sharpless. He was very enthusiastic about end uses for products especially those using asymmetric reactions: for example, gypsy moth pheromone. One memorable day found me helping Barry in a very large lecture hall with a cage of moths on one side and the pheromone containing trap on the other-except in the 
swirling air of that large room the moths were confused and flocked to me since I had been carrying all of this to the class (so much for demos!). I also was fortunate to know Professor Tom Allen at the Sloan School and he recruited a few of us to provide a diverse perspective in innovation classes he taught to industrial participants. There I learned a lot about communication and shepherding ideas through to innovation! As I continued into my career at Rohm and Haas, I realized I loved science and technology, but my real passion was in understanding customer needs and how products could be applied. I enjoyed my time in marketing in both plastics additives and coatings where I blended together my scientific knowledge and marketing skills.

The third major thread was an international focus MIT itself, certainly, but particularly special was a summer spent in Professor Henri Kagan's laboratory at the Universite Paris-Sud, Orsay. I found myself living with a French family just a few weeks after Barry and I discussed the opportunity - learning French and experiencing a new lab/country taught me even more about diversity of perspective and really listening. The chance to live overseas again finally arrived in 2006 and I spent an amazing couple of years living in Switzerland, building a team and engaging with customers in Western and Central Europe, the Middle East and Africa. There is no substitute for being there-truly hearing and experiencing what the customer really wants-my personal learning of people and places has been profound.

I feel remarkably fortunate that I was able to experience all of this early learning (whether I saw it as such at the time or not) and meld it into a rewarding career. I supplemented all of this along the way with lots of help from others - managers, coworkers, and community leaders from non-profit boards. These people provided mentoring, coaching, training and 'on the job' experiences that continued to not only hone my skills, but also helped me evaluate further what I wanted to do, how I wanted to combine all of my talents, and where I wanted to stretch for opportunities to gain new learning. I made the transition from marketing to finance to general management not by formal training, but by relying on my strengths, an eagerness to learn and reaching out to others for their expertise. Even now at Kleiner Perkins I am utilizing my skills in both technology and general management in our green technology group-and I still learn something new every day.

As I think about what has changed in the chemical industry compared to 20 years ago, I think the two most profound changes are in the access to, and speed of, information and the collaboration between historically separate fields: the capability to work together and combine chemical knowledge with many other fields, and do that globally, is amazing - biotech, materials science and so on. These combinations have opened up so many exciting opportunities for invention of new products biobased chemicals, new energy efficient materials, energy generation and storage...the list is endless.

I think women have more role models now and more access to them both in the workplace and in professional societies. However, there are still significant challenges, for both women and men, in how each person chooses to blend personal and professional time - I think the conversation is progressing, but remains very slow in some workplaces.

I spend a lot of time now mentoring others - "paying it forward"-it is part of what I think is essential to accelerating the progress - taking the time to listen to the questions and concerns of women early in their careers, sharing your perspective and experiences and helping them to explore the right answers for each of them. Sharing funny, outrageous and sometime poignant stories of your experiences - illustrating that often things don't go according to plan, but somehow they work out. Providing the view that if I had only done what I had planned twenty years ago I would have missed so much. Mentoring is one of the most rewarding things I do-a young woman sent me a note the other day: "Talking to you about all of this stuff helps me keep perspective and stay focused."

This short essay has only provided you with one example of what you can do with a degree in chemistry - there are SO many options! I urge you to follow your passions - do more of what you love. If you are interested in something, just ask - so many women (and men) are out there willing to listen to you, advise you, and connect you. With a career in chemistry, you can (still) go anywhere!

\section{Words saved me}

\section{Sharon L. Haynie (Figures 3, 4 and 5)}

The trajectory I've had in chemistry has been taken me further than I could have imagined as an 8th grader in 1968 when I proclaimed to my mother that I wanted to get a doctorate in chemistry and become a researcher. I was smitten with this molecule-based science I was exposed to in the special pilot course as evident by yearbook message from a junior high classmate who declared me "chemist" and "computer". Many cumulative acts born of prejudice or ignorance could have readily discouraged or derailed me as I progressed through my career as one of a "few" women or an "only" or a "first" black woman. However, fortune favored me with three saving graces. First, my passion and stubbornness that would resist anything that would deter me claiming this field that I believed was my rightful professional community. Second, even in the female-impoverished university and professional 


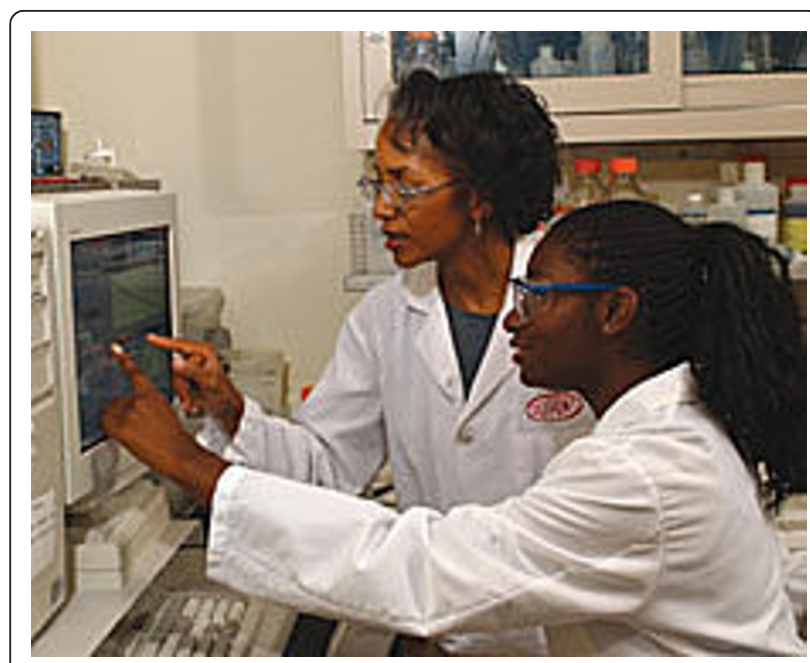

Figure 3 Sharon in 2003 with a former ACS Project SEED student - Vada Richardson. Photo from American Chemical Society career profiles page.

environments, I found that more doors were open than closed to me so I never lost faith that I could find a hospitable place in the halls of science. Finally- but most importantly -at an early formative age, I was

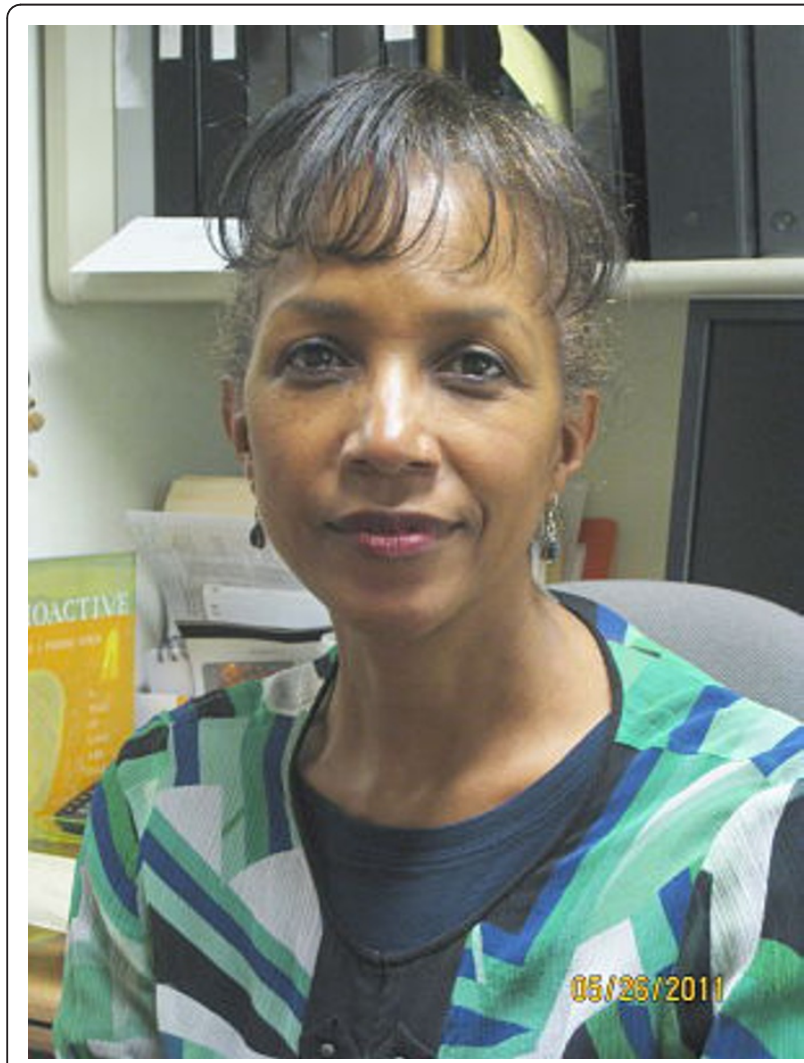

Figure 4 Photos of Sharon in her laboratory and from ACS career profiles page.

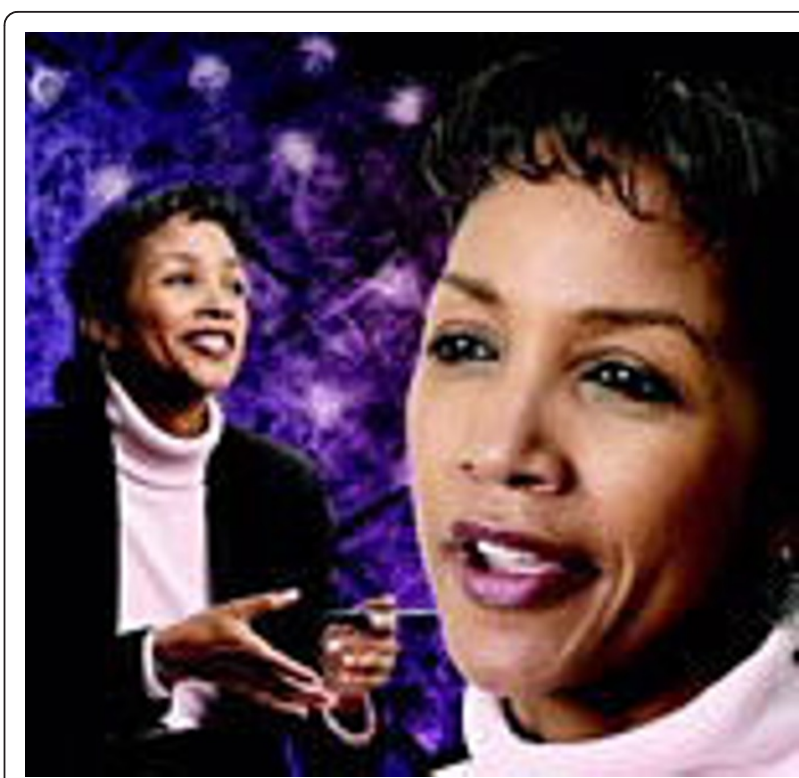

Figure 5 Photos of Sharon in her laboratory and from ACS career profiles page.

surrounded, supported and led in this journey by some key people - most prominent among them were women.

As I reflect, I now realize that I had for too long underestimated and discounted the critical role these dedicated women teachers played- they prepared me and propped me up for the emotional and mental challenges ahead. They were banking on me (and other women) to secure a place at the table of science that had largely been denied them. In an atmosphere charged with huge optimism for social change and expectations of grand success for those of us who were launched into this uncertain and rapidly changing future, they subtly "rehearsed" me for entry onto the grand stage of science using the power and conviction of their "words". The words offered welcome, wisdom, and warning. I could recite a litany of names but prominent among them were: Bockmiller, Carroll, Kaufmann, Leboy. My 5th and 6th-grade elementary teacher, Mrs. Patricia Riley Bockmiller, fostered academic independence and not letting limited resources [due to a de facto segregated school] deter my thirst and hunger for knowledge. She granted me freedom to intellectually explore outside the boundaries of the books we had and pushed me to do math on my own. My 8th grade science teacher, Mrs. Janet Carroll, moderated the special pilot early chemistry course and gave me a key affirmation on the final school day: "...you scored extraordinarily well in this national test, you should think about a career in science." Others openly shared personal stories to prepare me for facing inequities due to race and gender. In the all-girls public 
high school I attended, I developed a close relationship with Mrs. Olive Kaufmann, head of the chemistry department, who cultivated my interest in laboratory work allowed me to assist the chemistry laboratory manager, Mrs. Gloria Mazel. Mrs. Kaufmann shared a personal story of sacrifice that she had to make to retain a technical position in a manufacturing company. A male in her position would never have had to face that choice. But she and our schools' guidance counselors worked tirelessly to lure the recruiters from top engineering schools to advance the opportunities for the talented young women our Western High School for Girls had long produced. One school guidance counselor expressed to me her disappointment that I opted for University of Pennsylvania instead of M.I.T. for my undergraduate education. While I understood her aspirations for me, I thought that M.I.T. would be a better fit for me as a graduate student.

While these women educators were essential to my journey, I can't ignore the priceless gift I had in the example of my mother-a woman who broke barriers in gaining a foothold in several law enforcement positions in Baltimore-from whose experiences provided a context for me to find the fortitude to deal with barriers in my way. I was prepared to withstand heart-ache, hardship and disappointment in this journey. Looking back: yes, I had a professor who accused me of ignoring his letters to drop his course because he wrongly assumed that of the 4 women in his physical chemistry course of ninety-odd students, $I$ had to be the one with the failing grades-I couldn't be the person who had scored well above the median in the early exams. Yes, there was a professor among my graduate school chemistry faculty who would not take women students. Yes, on the advice of more senior women scientists at Bell Labs, I had my laboratory locked to prevent being a victim-apparently in the period preceding my arrival there had been acts of sabotage.

My positive experiences by far outstripped those negative acts. First, I received huge sincere support and nurturing when I was accepted as an undergraduate intern into the laboratories of Professors Edward Thornton, Arthur Humphrey and Britton Chance. I was strongly encouraged to pursue my aspirations in chemistry - and Dr. Humphrey was so much of a booster as to even strongly recommend a thesis advisor for me. One of a few women professors and my senior thesis research mentor, Professor Phoebe Leboy, provided me with the first hint that even in the atmosphere of the expectant change in the air of the 1970s; things were progressing at a snail's pace for women. She hinted that my graduate aspirations could be significantly compromised by my ignorance of the political realities of what it took to survive as a black woman in science. Again, a woman taking the initiative and time to share a story provided the ammunition I needed to quiet the seeds of doubt that could have sprouted and flourished.

Now, forty-odd years removed from my first formal encounter with chemistry, I can celebrate that the numbers of women scientists have grown appreciably in those educational and corporate communities and we offer more than words-they are visible doing works that are truly key and central to the enterprise of science. We are no longer so few that our small number would fill a single restroom. I've witnessed a generation of women of color gain appointments in tier one and tier two faculties in chemistry and chemical engineering. The environment-although still imperfect - has become at the very least family-tolerant so I no longer hear women professionals whisper about the unwritten practice of maternity leave "penalty". Whereas in the late $70 \mathrm{~s}$ and $80 \mathrm{~s}$, it appeared that the cost of gaining leadership was to sacrifice bearing children, I now see women leaders who have raised children. And as for those leadership levels: the ceiling has risen and I am proud to being associated with two academic institutions and a Fortune 500 corporation that can boast a woman at the helm. Could I have imagined in 1968 that in 2009 the world would herald 3 women scientists as noble laureates?!

While there is still much work to do to achieve full gender and race equity in science, I genuinely nod in agreement with a line in the refrain of the gospel hymn "How I got over": my soul looks back in wonder!

\section{Synthesizing a Career through Chemistry \\ Paula J. Olsiewski (Figure 6, 7, 8 and 9)}

It was mid April, 1971, decision time for colleges. I fell in love with chemistry in high school and wanted to pursue a career in chemistry. Where would I go to

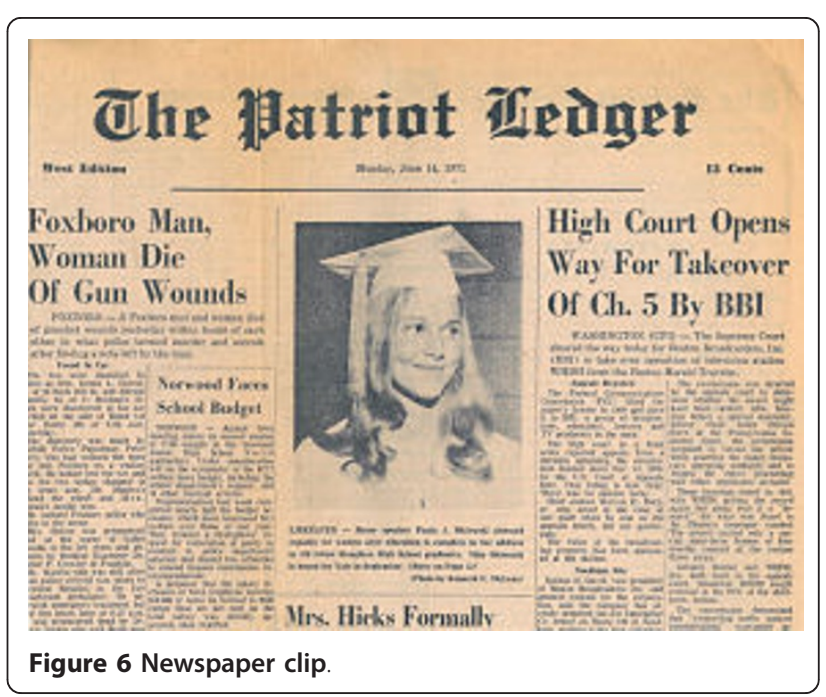




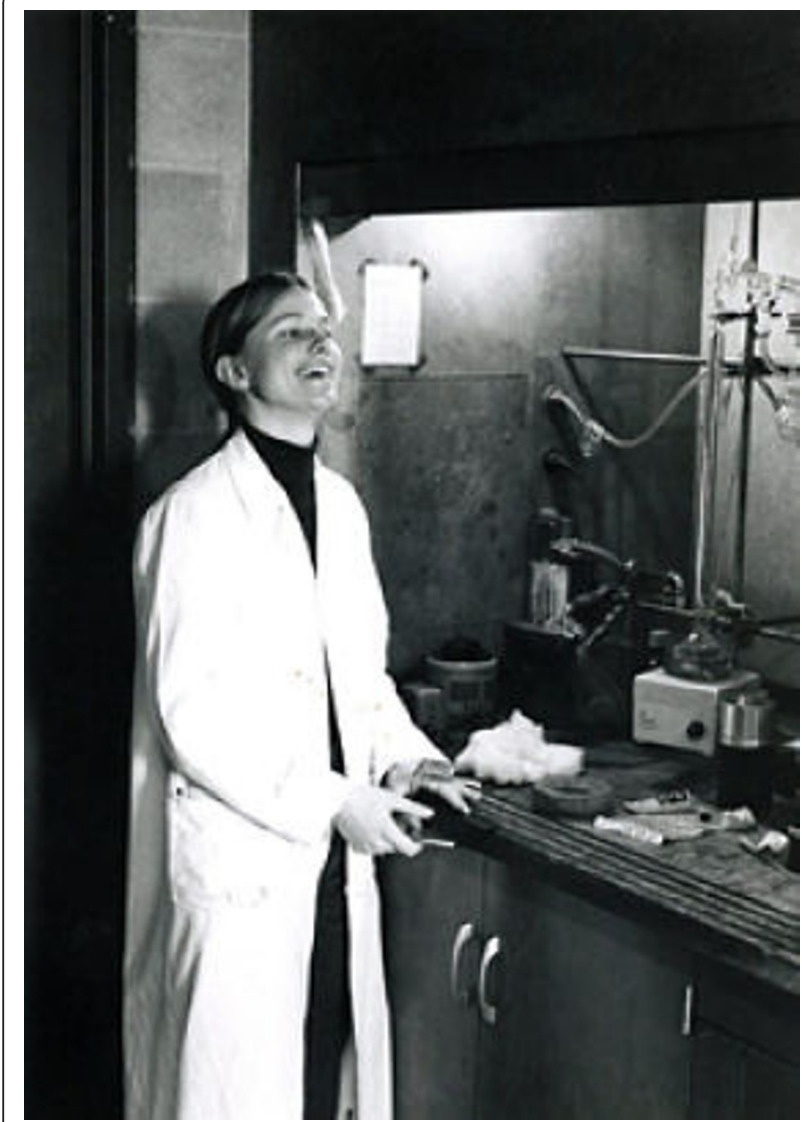

Figure 7 Photo in Blout lab taken by Charles Deber

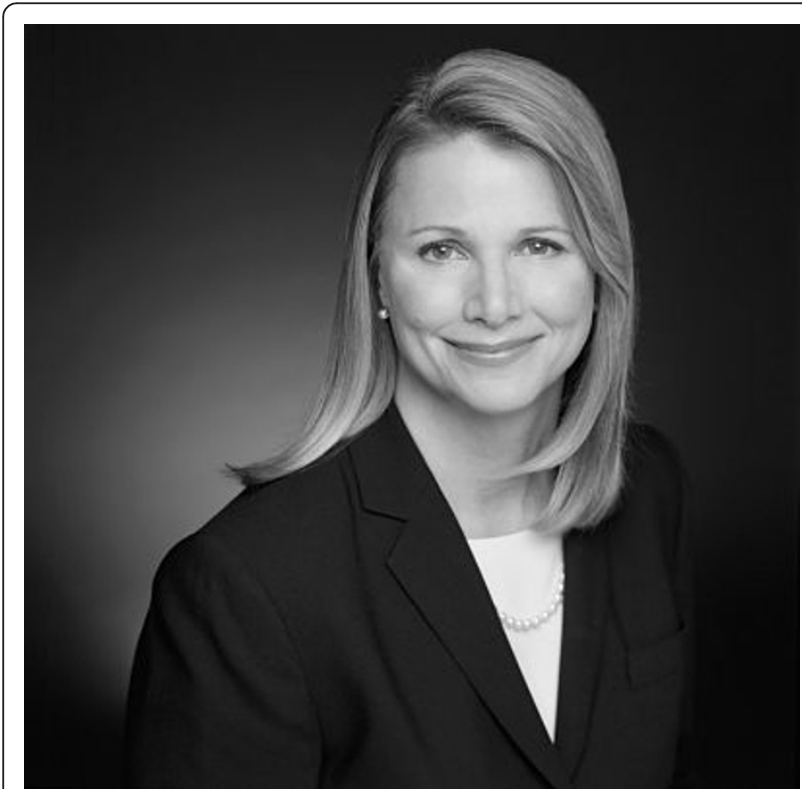

Figure 8 Photo by Michael Frost.

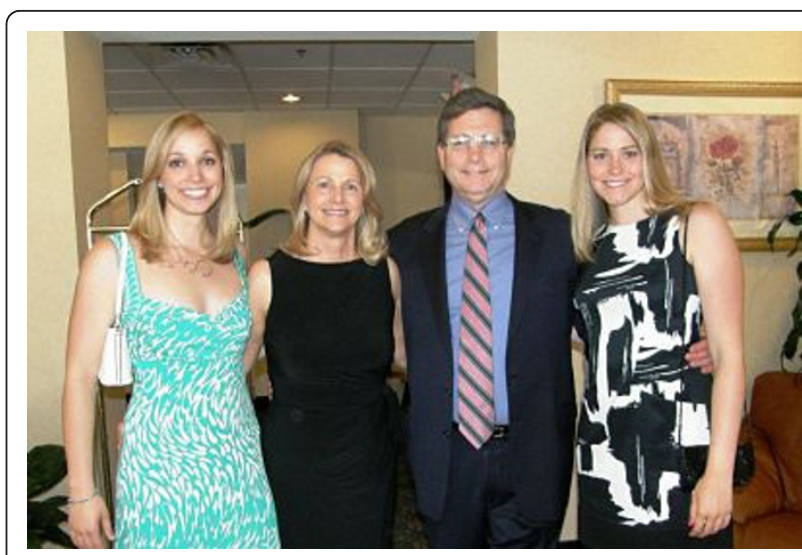

Figure 9 PJO today with her family, from left to right, daughter Georgia Healey, PJO, husband John Healey, and daughter Vivian Healey.

study? With great trepidation, I opened the mailbox, and then screamed with delight when I discovered a fat envelope from Yale. Not only was I accepted, but I with the scholarship I needed. Yale, a male bastion for 268 years had gone co-ed just two years earlier and now I was one of the 250 girls in a class of 1250 who would become the Yale College Class of 1971! The topic for my high school valedictory address was equal rights for women, which was a controversial subject for many at the time. The next day, there was a front page story on me in the local newspaper, complete with a photo.

In September, I arrived at Yale. It was exciting and a bit scary. The university and the faculty were not yet comfortable with women - but they were trying. Admitting women required changes in infrastructure- dormitories, bathrooms, locker rooms- and attitudes. Women were no longer weekend visitors looking to meet a Yale husband but were intellectual equals who belonged in the classrooms at Yale. Some Yale men felt threatened after all, if only 250 of us got in, we had to have better grades, SAT scores, and so forth than the average male who was admitted.

Chemistry at Yale was challenging but I stayed with it. Whenever possible, I avoided situations that seemed hostile to women. Sally Chapman, now on the chemistry faculty at Barnard, was my TA and provided insight and encouragement- but I don't recall many women in the chemistry department. Somehow, sophomore year I got a work study position with organic chemistry Professor Harvey Wasserman. I don't know if it was a co-incidence, but his wife, organic chemist turned administrator Elga Wasserman, was in charge of co-education at Yale.

I don't think there were any women in the Wasserman group- but the group embraced me and I helped the post docs with organic syntheses and purifications. I 
attended group meetings and my interest in chemical research was nurtured. Through a recommendation from Professor Wasserman, I landed a wonderful summer job synthesizing cyclic peptides in Professor Elkan Blout's lab at Harvard Medical School.

It was there that I developed a strong interest in studying the chemistry that went on in biological systems. I applied to and was accepted to a number of PhD programs in chemistry- but I was cautious. I needed to find a top chemistry department that was receptive to women, and MIT seemed to fit the bill. I was grateful for the advice provided by two of my Yale chemistry professors who gave me the names of the MIT chemistry faculty who did NOT take women in their labs.

The transition to being a graduate student at MIT was traumatic. I was lonely, struggling with the course work, and was thrust into being a teaching assistant without any instruction on how to teach. There were 10 women in my class of 50 students. There were two women on the faculty, neither of whom had a future with the department. I detected lots of sexism in the department - but not in assistant Professor Christopher Walsh's laboratory, whose research group I joined. It can be risky to do your $\mathrm{PhD}$ thesis with an untenured faculty member, but Chris was confident and his lab already included several women. Was it a coincidence that he was my Yale TA Sally Chapman's brother in law? I made lifelong friends in the Walsh lab as I pursued my research studying $\mathrm{D}$-amino acid dehydrogenase and graduated with a PhD in biological chemistry in 1979.

During graduate school, I married my college boyfriend, John Healey, who was finishing medical school and now we faced the two body problem. We solved it by moving to New York City in 1979 where I would do a post doctoral fellowship and he would do his residency.

During my post doc, I wasn't looking for a job but I liked meeting people and learning about opportunities. One day, I went to lunch with some people from a small biotech company, Enzo Biochem, Inc. I was pulled into the direction of business. It seemed exciting and practical. A few months later, I was working at Enzo, at the interface of science and business. I left the lab and never looked back.

I had amazing opportunities for professional growth and development at Enzo. During my nine years there, I worked in a variety of roles developing in vitro diagnostic products. I worked on patents and negotiated licensing agreements. I established good manufacturing practices, conducted clinical studies, and learned how to take products through the FDA. I also gave birth to my two daughters. I really enjoyed my work and enjoyed being a mother.
I left Enzo after I hit and broke through the "glass ceiling." Around this time, I had an intriguing job offer from a biotech startup in Boston - but I wasn't interested in moving. I entered an entrepreneurial phase and developed a consulting practice in technology assessment, which continued for nine years. The work was varied. For one client, I established a tech transfer office. For another, I ran a state funded program to build bridges between local scientists and local biotech companies.

During this time, I began fundraising for MIT and in 1994, I was appointed by the MIT Corporation (the Board of Trustees) to serve on the MIT Visiting Committee in Chemistry, an advisory group that meets every two year to evaluate the Chemistry department and reports back to the MIT Corporation. I was shocked by my first meeting. 15 years after my graduation, MIT still had only two women on the faculty. In those 15 years, MIT had produced at least 150 women PhD chemists- but not one was worthy of an MIT job offer. What was wrong here? I was determined to find a way to help the chemistry department faculty go co-ed! Why didn't women apply for the jobs? What was the chemistry department doing to engage women? I was relentless. I had meeting with lots of people at MIT to engage them on what I viewed as a very serious problem. Fortunately, they were willing to talk to me - I am sure it helped that I also was a decent fundraiser for MIT. I met with the President, Chuck Vest, the Provost, and chemist Mark Wrighton, the Dean of the School of Science Bob Birgenau, and the chemistry department leadership Bob Silbey, then Steve Lippard and Rick Danheiser. While success has many parents, I credit Rick Steve and Professor Joanne Stubbe for making some big changes in the department and taking bold steps, such as identifying and recruiting Catherine Drennan before she even started her post doc, and then recruiting senior faculty Barbara Imperiale, an MIT graduate. Unbeknownst to me, while I was making waves in the MIT chemistry department, Nancy Hopkins and her women colleagues in the school of science was making bigger waves at MIT. The good news is that the chemistry department changed for the better and women became willing to invest their careers at MIT. Today there are seven women on the faculty.

In 2003, I became President of the MIT Alumni Association and served on the committee that selected Yale neurobiologist Susan Hockfield as the next President of MIT. I served as a member of the MIT Corporation from 2004-2009, where I had new opportunities including serving as an advisor to the MIT Initiative on Faculty Race and Diversity.

After 15 years, I have completed my service on the MIT Chemistry Visiting Committee - there may be different opportunities for me in chemistry. Since 2000, I 
have been a program director at the Alfred P. Sloan Foundation where I am responsible for funding basic scientific research and science policy research. At Sloan, we identify important problems, find smart people with good ideas for addressing those problems, and then fund them. I direct our programs in Biosecurity, Synthetic Biology, and the Indoor Environment. As our Biosecurity program winds down, I need to develop a new program area, this time in chemistry.

\section{Trial by fire}

\section{Mary Roberts (Figure 10)}

30 years ago, the dark ages in the minds of my present students, I was a junior faculty in the M.I.T. Chemistry Department. What I remember most is the feeling of isolation in a sea of males (initially with one other female who had already been abandoned as a viable colleague). Those males were as perplexed as I was on how they should deal with me. Most practiced avoidance.

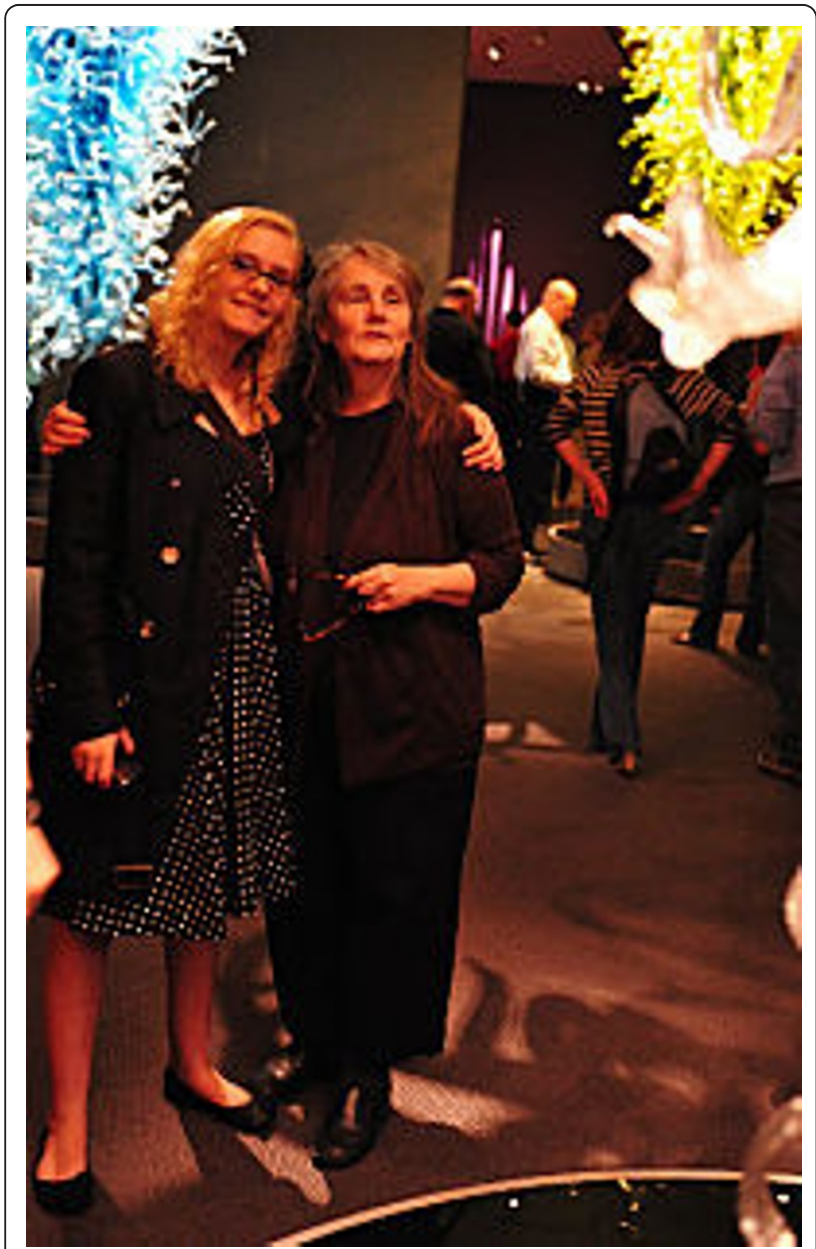

Figure 10 Photo of Mary, on left. I am with my 'baby' at the Chihuly exhibit at the MFA... chemistry in all that beautiful colored glass!.
There was always this nagging lack of a mentor. Did I have a disease? Nope, just two X chromosomes . . . Floundering was easy, especially if you weren't sure of the 'rules' of engagement. Trying to make an imprint in science was hard then and maybe harder now - I certainly didn't have the personality to do it. My husband describes me as stubborn and oblivious much of the time with a habit of wandering off in research directions not currently in vogue. In retrospect, it is the small episodes that linger in my mind - made me grin, others still can hurt. The one of my colleagues who at least tried to deal with me was Dan Kemp, an organic chemist. As one of my neighbors in the bowels of the basement of building 18, he at least tried to help on occasion. I can close my eyes and see the scene one afternoon as he was trying to calm me down. I don't remember what upset me but I was clearly hurt, mad and very inarticulate about something ... He invited me into his office - no fluorescent lighting but a soft incandescent glow - to look at some of his gems ... such beautiful stones. I didn't have to know much about them to appreciate what they were. Those stones had a beauty and permanence that was somehow reassuring. You can find wonderful things that make bad things slip away, at least temporarily.

Perhaps the best things about being a faculty member are the students - both undergraduate and graduate. At M.I.T., members of the first group were enthusiastic, often a bit inarticulate, but almost always interesting. One undergraduate who stood out was a poetic sole for whom I was a freshman advisor. Over the course of his first year he found himself enthralled with language - a poet trapped in a technology institute. Somewhere I still have the dog-eared paper with a few poems he dashed off ... I often wonder what happened to him. Another who did research in my lab seemed to always start a conversation with me somewhere in the middle - I think he started it in his mind and just forgot that I wasn't actually there. That provided interesting lessons in communication. Some of the memories are sad - a freshman who was diagnosed with nasopharyngeal cancer - he didn't make it but tried so hard I was sure he would survive.

In the second group were the graduate students and watching them grow as scientists and individuals was delightful. I loved talking with my graduate students, suggesting experiments and ideas that often were a bit whacky. They would reel in ideas and were absolutely crucial to the moderate success I had. But other chemistry graduate students also left distinct impressions. One, with a more biological bent, was a violist - a good scientist but perhaps a better musician? I love music and was really curious about his talent. I was lucky to have him perform a recital in my office that exposed a very 
different side of him. I treasure the memory of that little concert because I actually got a glimpse of who this young man really was. He ended up working in an area I knew little about. I hope he never put away his viola.

Teaching? I wasn't very good at it - I don't think I had a clue - it all seemed trial by fire. I am delighted that these days a large number of institutions have seminars for post-docs on what it takes to transition into a successful career in academia. It is nice to know the rules of the game before you start. Understanding what is expected in specifics is critical to success. One of the things I enjoy today is watching my junior colleagues, particularly the female ones, develop research programs. I hope the funding crisis abates so that there is a succession of enthusiast, young scientists (particularly women) willing to teach and inspire new students.

Again, the most unpleasant things I endured at M.I.T. were isolation and an awkwardness in interactions with colleagues. I don't think I helped the situation - I am not a let's-go-out-for-beers-or-play-some sports individual ... At the time I was also trying to raise a family if you want one you pretty much have to juggle its needs with those of graduate students, research, teaching, etc. I tried to keep home and work separate and was not always successful but knew it was absolutely necessary to be taken seriously. Into the funniest/awkwardest moments was when I was quite visibly pregnant with my son. Most of my colleagues seemed afraid to look at that large and rather obvious belly. However, they didn't want to look at my face either - the neck seemed safe ground ... They were especially uncomfortable if trapped in an elevator with me. There would be a moment of sheer panic - as if I were a grenade with the pin out and ready to blow any moment. I rather relished those elevator rides...

The worst of these uncomfortable experiences was not getting tenure. The decision was made, and I was informed. I still think my chairman thought I would burst into tears or otherwise fall apart, and I was glad that I didn't . . . I hope sometime in his life someone in authority talked to him in a similar condescending way and made him feel as inconsequential and worthless as he made me feel. Yes, not receiving tenure was annoying and disappointing, but what was worse was that once this occurred I became invisible. If I were in an elevator with a colleague, he would become busy pouring over a paper or talking intently with a student. Not getting tenure I could handle - becoming invisible I couldn't to this day it still hurts. When I have talked with other 'failed' academics I have found they often had the same experience. Once a negative decision is made you cease to exist... . even though you are still there and need help in figuring out what to do next. I am not sure it's any better today.
However, life is short and there have been so many wonderful things to experience that most of my memories of M.I.T. are faint - the bad ones buried by the truly wonderful interactions with students and an occasional colleague ...

\section{Count All Trials and Tribulations as Joy}

\section{Amber S. Hinkle (Figure 11)}

I believe we should count all trials and tribulations as joy, or in other words, if someone tells me I can't do something - I strive very hard to do it. As a successful woman chemist, I have many examples of being motivated by being told I can't accomplish something. I've learned a few things along the way; about myself and life in general.

I was fortunate to have few trials and tribulations growing up. In fact, learning came naturally and by high school I was quite bored until two teachers motivated me. First, my chemistry teacher finally challenged me academically and made science interesting. Then my biology teacher told us girls that if we found biology too

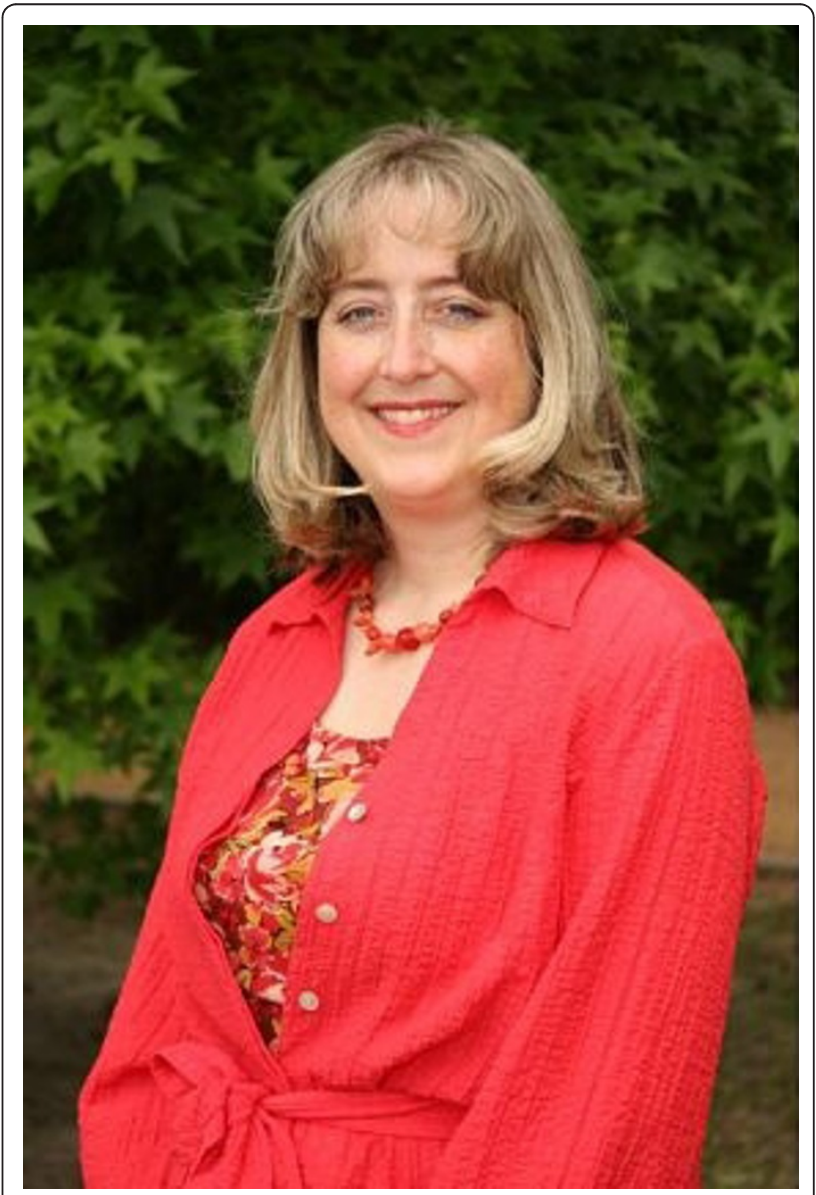

Figure 11 Photo of Dr. Amber S. Hinkle, Director HSEQ-OS, Bayer Material Science, Baytown, Texas 
hard, we could get extra credit by picking weeds in the baseball practice field. You can guess which teacher was a woman. I spent all 3 years of high school taking chemistry, learning that it is totally awesome, and I've been hooked ever since.

As I prepared to go to college, I took several advanced placement exams, including the one for chemistry. I began my undergraduate studies as a sophomore, starting with organic chemistry, after being told that I probably shouldn't. It was nice to have one other woman in the organic class and all went well. In fact, I learned a few years later that this was definitely the right choice because "freshman chemistry" was boring enough to teach some days, let alone having to have taken it. Thus if you want someone to learn and remember, make whatever you're saying interesting, relevant and fun. Fortunately there are many more women in today's chemistry classes as well.

While pursuing my undergraduate degree, I had the opportunity to work with one of the national labs, not only during the summers but also throughout one school year. Of course this was not looked on as wise by some. Three other women chemists and I spent six months running a special environmental treatment pilot plant as part of an away assignment. The study required us to work 12-hour shifts, with a cycle of 21 days working and 3 days off. This was seen as much too dangerous and difficult for us but we were very successful none the less. In order to take this assignment and still meet my personal goals, I carried 28 credits and finished my degree in 8 quarters. I learned that hard work and perseverance do pay off. Also you must seize opportunities because no one will seize them for you.

This experience set me up nicely to accept a full-time position at the national lab, continuing on with similar projects. Having gained some expertise through running the pilot plant, I was disappointed when my ideas were given little credit, presumably because I didn't have a Ph.D. I also noticed the gender ratio of lab technicians to "official scientists" was quite skewed. Thus I set off to graduate school, again highly motivated. Today women populate the scientific field at all levels to a much greater degree than ever before.

My journey continued with me accepting the research project that no one else wanted because it had hit a particular snag. After I too battled this roadblock, I decided to seek help from some external experts. This wasn't necessarily a common practice in academia at that time but it made sense to me. This external information I received cleared that graduate school hurdle. Teaching me that teamwork and collaboration can be very valuable. Additional motivations included being told that I couldn't possibly complete my Ph.D. in the time I had planned, especially if I continued to live 1.5 hours away and work in the lab primarily only weekdays. Fortunately my research advisor was a great mentor for me and encouraged me along the way. I finished in four years.

I next set my aim on finding a job in industry, without doing a postdoctoral assignment. This was two strikes, according to some. However thus began my career in chemical manufacturing. I took a good job with a company that held the opportunity for a lot of other career moves in the future. Finding the perfect job is a dream come true but remember to look for potential in unexpected places too.

I experienced many trials and tribulations my first year in the new job, some due to being a woman. There was a clear difference in treatment based on gender. However I can honestly say that this was not a widely held philosophy. In fact, when these differences became more than personal and began to effect business decisions in the department, speaking up did get the issues resolved. I learned that nothing is worth being miserable at work every day and that I do have a choice. This is sometimes easier said than done but I encourage everyone to take this to heart.

Within two years, I re-located to the heart of largescale chemical manufacturing along the Texas gulf coast, by seizing an opportunity within my company. This is a physically and mentally demanding environment. Over the last 15 years, many more women have entered it but there is still room for more. Initially I had to let my colleagues know that, contrary to popular belief, I was not working nights to cook for the operators but rather to learn the chemical process. I also remember one colleague asking in a training session why us women didn't want to stay home and sew or something. This was in 1998. Fortunately attitudes and opportunities have changed for the better. The true value of diversity is widely recognized and growing.

In conclusion, there are two final lessons I've learned over the years that I would like to emphasize. The first is that the value of participating in a professional organization can be tremendous. I have been active in the American Chemical Society for 20 years. This gave me the opportunity to develop my leadership skills in a "safe" environment and build a tremendous network. As Chair of the national Women Chemists Committee (WCC) for three years, it was very rewarding for me to advocate for women chemists everywhere. Also the WCC has gathered success stories from many, many women chemists - which they've shared so that we can learn from one another.

The second lesson I want to emphasize not only applies to me but also was voiced by almost every successful woman chemist the WCC interviewed. Mentors are key to your success. They come in all shapes, sizes 
and genders. They can be both informal and formal. You can receive advice, trial your own ideas, as well as learn what works and what doesn't from mentors. Cultivate mentors for yourself and be a mentor to others.

I am now responsible for Health, Safety, Environment, and Quality at Bayer's largest chemical manufacturing plant in NAFTA. I still think chemistry is awesome and I get to make sure we use it to improve people's lives while protecting our employees, our community and the environment. While I've often been motivated by being told I can't, I try to encourage others by telling them they can. Join me in looking for joy every day and keeping the faith!

\section{About the authors}

Nancy L. Jones (jones@lasalle.edu) is professor of chemistry and a founding director and chair of the Integrated Science, Business and Technology Program at La Salle University.

Cheryl A. Martin (camartin12@yahoo.com) is in the green technology group of Kleiner Perkins Caufield \& Byers.

Sharon L. Haynie (sharon.L.haynie@usa.dupont.com) is a principal investigator in the Central Research Department of the DuPont Company.

Paula J. Olsiewski (olsiewski@sloan.org) directs the Indoor Environment and Biosecurity programs as well as the Synthetic Biology Initiative at the Alfred P. Sloan Foundation.

Mary F. Roberts (mary.roberts@bc.edu) is professor of chemistry at Boston College.

Amber S. Hinkle (amber.hinkle@bayerbms.com) is director for Health, Safety, Environment and Quality at the Baytown, Texas manufacturing plant of Bayer Inc.

\begin{abstract}
Author details
${ }^{1}$ Central Research Department, DuPont, Wilmington, Delaware, USA. ' Health, Safety, Environment and Quality department, Bayer Inc., Baytown, Texas, USA. ${ }^{3}$ Integrated Science, Business and Technology Program, La Salle University, Philadelphia, Pennsylvania, USA. ${ }^{4}$ Green technology group, Kleiner Perkins Caufield \& Byers, Menlo Park, California, USA. ${ }^{5}$ Indoor Environment and Biosecurity program, Alfred P. Sloan Foundation, New York, NY, USA. ${ }^{6}$ Boston College, Chestnut Hill, Massachusetts, USA.
\end{abstract}

Received: 4 July 2011 Accepted: 7 November 2011 Published: 7 November 2011

doi:10.1186/1752-153X-5-69

Cite this article as: Haynie et al.: Reflections on the journey: six short stories. Chemistry Central Journal 2011 5:69.

\section{Publish with ChemistryCentral and every scientist can read your work free of charge \\ "Open access provides opportunities to our colleagues in other parts of the globe, by allowing anyone to view the content free of charge." W. Jeffery Hurst, The Hershey Company. \\ - available free of charge to the entire scientific community - peer reviewed and published immediately upon acceptance \\ - cited in PubMed and archived on PubMed Central \\ - yours - you keep the copyright \\ Submit your manuscript here: \\ http://www.chemistrycentral.com/manuscript/<smiles>c1ccccc1</smiles> ChemistryCentral}

